\title{
Contribution to the knowledge of Pleurobranchus testudinarius Cantraine, 1835 (Gastropoda Pleurobranchida) along the central- eastern coast of Sicily (Ionian Sea)
}

\author{
Andrea Lombardol,* \& Giuliana Marletta' \\ ${ }^{1}$ Department of Biological, Geological and Environmental Sciences, University of Catania, 95124 Catania, Italy \\ *Corresponding author, e-mail: andylombardo94@gmail.com
}

\begin{abstract}
Pleurobranchus testudinarius Cantraine, 1835 (Gastropoda Pleurobranchida) is one of the largest and most conspicuous species of marine heterobranchs. However, although this species is a well-known at morphological level, little is known about its biology. Through continuous observations (from 2017 and 2020) conducted during morning scuba dives in some areas located along the central-eastern coast of Sicily, data relative to the egg masses of $P$. testudinarius were collected. Moreover, through occasional night dives, several adults were encountered and observed in their natural habitat. Through this study, it was noticed that: 1) P. testudinarius is a nocturnal species; 2) it lays exclusively in summer; 3 ) this species might have an annual or biennial life cycle; 4) it was documented that the polychaete Hermodice carunculata feeds on the egg masses of this pleurobranch; 5) probably at the end of its cycle, this species is subjected to attacks of predators.
\end{abstract}

KEY WORDS Egg masses; Hermodice carunculata; Marine Heterobranchia; Pleurobranchus testudinarius; Sicily.

Received 03.07.2021; accepted 29.10.2021; published online 16.12.2021

\section{INTRODUCTION}

Pleurobranchus testudinarius Cantraine, 1835 is one of the largest and most conspicuous species of marine heterobranchs, which belongs to the order Pleurobranchida (Gastropoda: Heterobranchia) (Trainito \& Doneddu, 2014; Ergüden et al., 2019). This species is distributed in the Mediterranean Sea, in the islands of Macaronesia (Canary Islands, Selvagens Islands, Madeira and Azores) and along the coasts of Brazil (Pruvot-Fol, 1954; Marcus, 1970; Barash \& Danin, 1971; CattaneoVietti, 1986; Yokes, 2002; Cervera et al., 2004; Poursanidis, 2007; Poursanidis et al., 2009; Trainito \& Doneddu, 2014; Ergüden et al., 2019; Ballesteros et al., 2021). Pleurobranchus testudinarius presents a yellow-ochre or red-violet body colouration with a darker dorsal surface of the notum (Figs. 1, 2).

The body, with elliptic shape, has a swollen aspect with a dome shape. The notum is large and covers the whole body. Its edges are often thin and wavy. The anterior part of the notum shows an evident triangular-shaped recess. Along almost all the notum there are several tubercles of different sizes. The more dorsal ones are big and cone-shaped, arranged in a symmetrical way. These tubercles are bordered at their base by violet, pink, lilac, or purple polygonal rings. Along the sides and edges of the notum there are smaller tubercles. Collectively, the position, the aspect and the shape of tubercles seems to a turtle carapace. Instead, the inferior surface of the notum is smooth. The oral veil is small and trapezoidal. Rhinophores are long, 


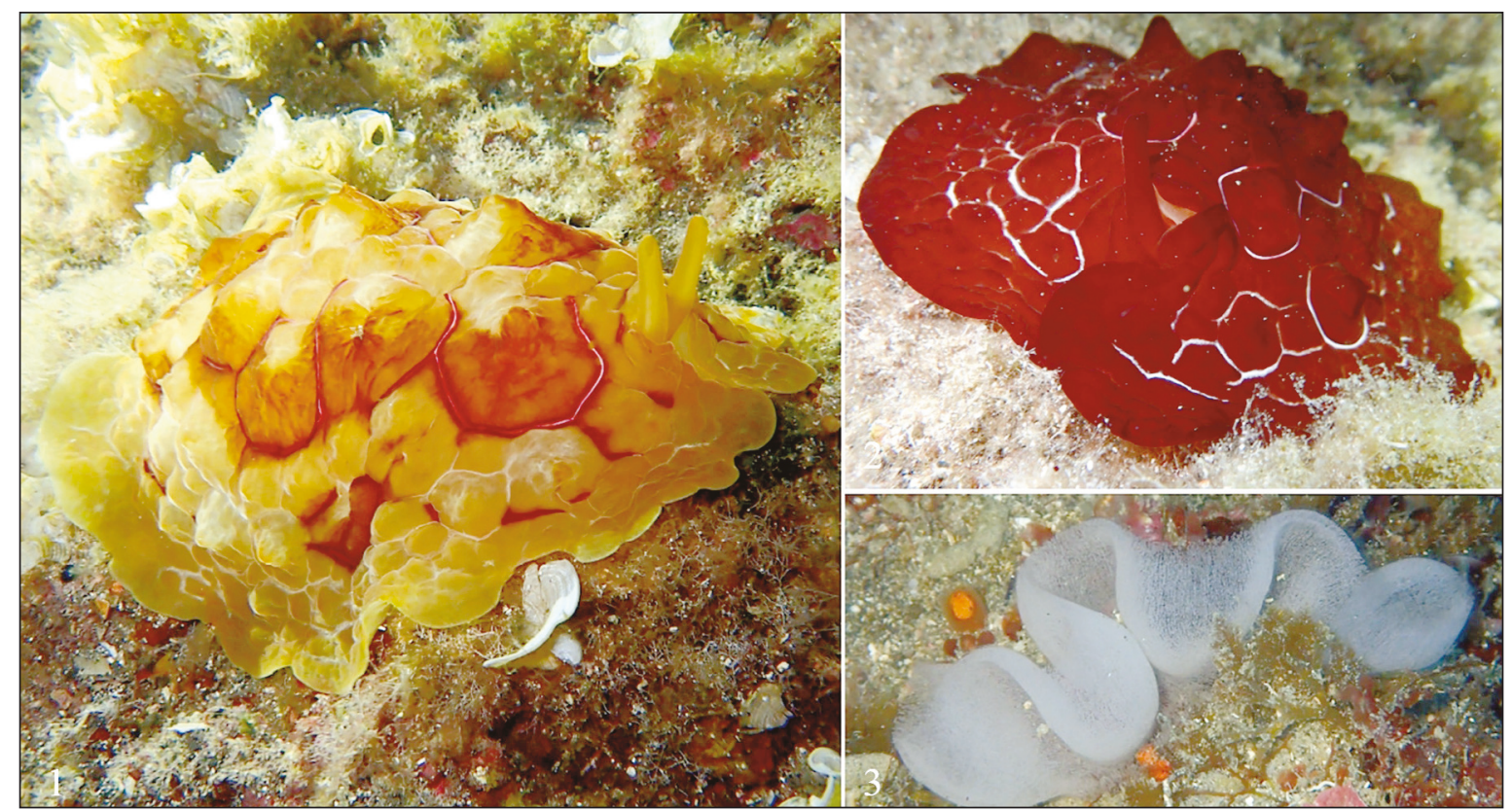

Figures 1-3. Pleurobranchus testudinarius specimens and their egg masses from the central-eastern coasts of Sicily. Fig. 1: right latero-dorsal view of a yellow-orange specimen. Fig. 2: anterior view of a red-violet specimen. Fig. 3: an egg mass of P. testudinarius (photos by A. Lombardo).

slightly swollen at the base and tube-shaped. The foot is smaller than the notum. The large tuberculate gill, on the right side of the body (hidden by the notum), presents from 18 to 30 pinnules on each side of the rachis. Pleurobranchus testudinarius can reach 190-200 mm of length and 85-135 mm of width (Vayssière, 1898; Cattaneo-Vietti, 1986; Trainito \& Doneddu, 2014; Ballesteros et al., 2021).

The egg masses (Fig. 3) are white coloured, ribbon-shaped and with only one of the edges attached to the substrate. These ribbons can present a length of more than $10 \mathrm{~cm}$ and, overall, have a characteristic rosette shape. Just before hatching, they acquire a pinkish colouration (Bandel, 1976).

Pleurobranchus testudinarius would seem to have nocturnal habits (Ballesteros et al., 2021). In fact, this species has often been found in open environments only during the night, while during daytime it stays hidden in crevices (Wirtz \& Martins, 1993; Ergüden et al., 2019; Ballesteros et al., 2021). This pleurobranch was detected on several substrates: Zostera Linnaeus in bottoms between 20 and $35 \mathrm{~m}$ of depth (Vayssière, 1898), into submarine caves (Ros \& Gili, 1984), sandy to muddy bottoms (Cattaneo-Vietti, 1986; Yokes, 2002; Horst,
2008), muddy with Caulerpa racemosa (Forsskål) J. Agardh (Mpardanis, 2007), rocky substrata covered by algae (Poursanidis, 2007; Poursanidis et al., 2009; Ergüden et al., 2019), sand and Posidonia König meadows (Poursanidis et al., 2009) and stony place (Gökoğlu et al., 2018). The stomach content exam of some specimens studied by Cattaneo-Vietti (1986) highlighted that $P$. testudinarius probably feeds on colonial tunicates. Moreover, during that study, he found in the stomach several specimens, also some bivalves [in the specific Musculus subpictus (Cantraine, 1835)] and algal fragments.

Although $P$. testudinarius is a well-known species at morphological level (Vayssiere, 1898; Cattaneo-Vietti, 1986; Martynov \& Schrödl, 2009), little is known about its biology (Ballesteros et al., 2021). Consequently, the aim of this study is to expand the knowledge on the biology of this peculiar mollusc. In the specific, this research will shed light on the laying period of this species and will describe some observations conducted from the authors throughout the years of study along the central-eastern coast of Sicily, where $P$. testudinarius is usually present (Lombardo \& Marletta, 2020). 


\section{MATERIAL AND METHODS}

The present research was carried out between 2017 and 2020 in different localities sited along the central-eastern coast of Sicily (Figs. 4, 5). These sites were selected according to different environmental conditions, which characterise each of them. The southernmost localities, "Ognina" (37³1'50.4”N

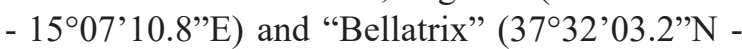
$\left.15^{\circ} 07^{\prime} 35.2^{\prime \prime} \mathrm{E}\right)$, are both situated within the municipality of Catania. Both sites present a severe anthropic impact due to the huge presence of apartment buildings and bathing establishments along the entire coast. Furthermore, in their immediate vicinity, there are a touristic harbour and a wastewater outfall. Given the great similarity of the environmental conditions and the proximity (about $540 \mathrm{~m}$ ) between these two sites, they were considered as a unique site called from now on "Catania". The northernmost localities, "Scalo Pennisi"

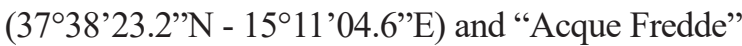
(37 $\left.38^{\prime} 15.7^{\prime \prime} \mathrm{N}-15^{\circ} 10^{\prime} 52.1^{\prime \prime} \mathrm{E}\right)$, are both situated within the hamlet of Santa Tecla, belonging to the municipality of Acireale. Both sites present the most natural environmental conditions among the examined localities of this study. Also in this case, due to the environmental similarity and their proximity (about $390 \mathrm{~m}$ ), they were considered as a single site named "Santa Tecla". Instead, the site "Santa Maria La Scala" (37³6'46.5” N -15'10'31.4” E), located within the homonymous hamlet of the municipality of Acireale, presents intermediate environmental conditions between Catania and Santa Tecla.

Data were collected through scuba dives performed twice a week (weather conditions permitting) throughout the period of study (2017-2020). In total, 311 scuba dives (119 in Catania, 92 in Santa Tecla and 100 in Santa Maria La Scala), lasting at least one hour, were carried out between 9:00 and 11:30 a.m.. Each dive was conducted between 0 and $45 \mathrm{~m}$ of depth (according to the sea bottom), following the same path for each site. All the specimens of $P$. testudinarius encountered and their egg masses were photographed with an Olympus TG-4 underwater camera. Subsequently, the examined photos were used to obtain information on the number of specimens and egg masses; and on the type of substrate where they were found. In the sites examined from 2017 to 2020 almost only the egg masses were detected. Consequently, for Catania, Santa Tecla and Santa Maria La Scala, some graphs, showing the total number of egg masses found in each month, were realized through Excel. Due to the Covid-19 lockdown, it was not possible to carry out dives in April 2020.

Together with the abovementioned sites examined between 2017 and 2020, it was considered another site called "Padre Pio" (37 33'57.8" N $15^{\circ} 9^{\prime} 58.8^{\prime} \mathrm{E}$ ) that is located in the zone "B" (general reserve zone) of the "Ciclopi Islands" MPA, in the hamlet of Aci Trezza, within the municipality of Acicastello. In this site, some night dives (con-

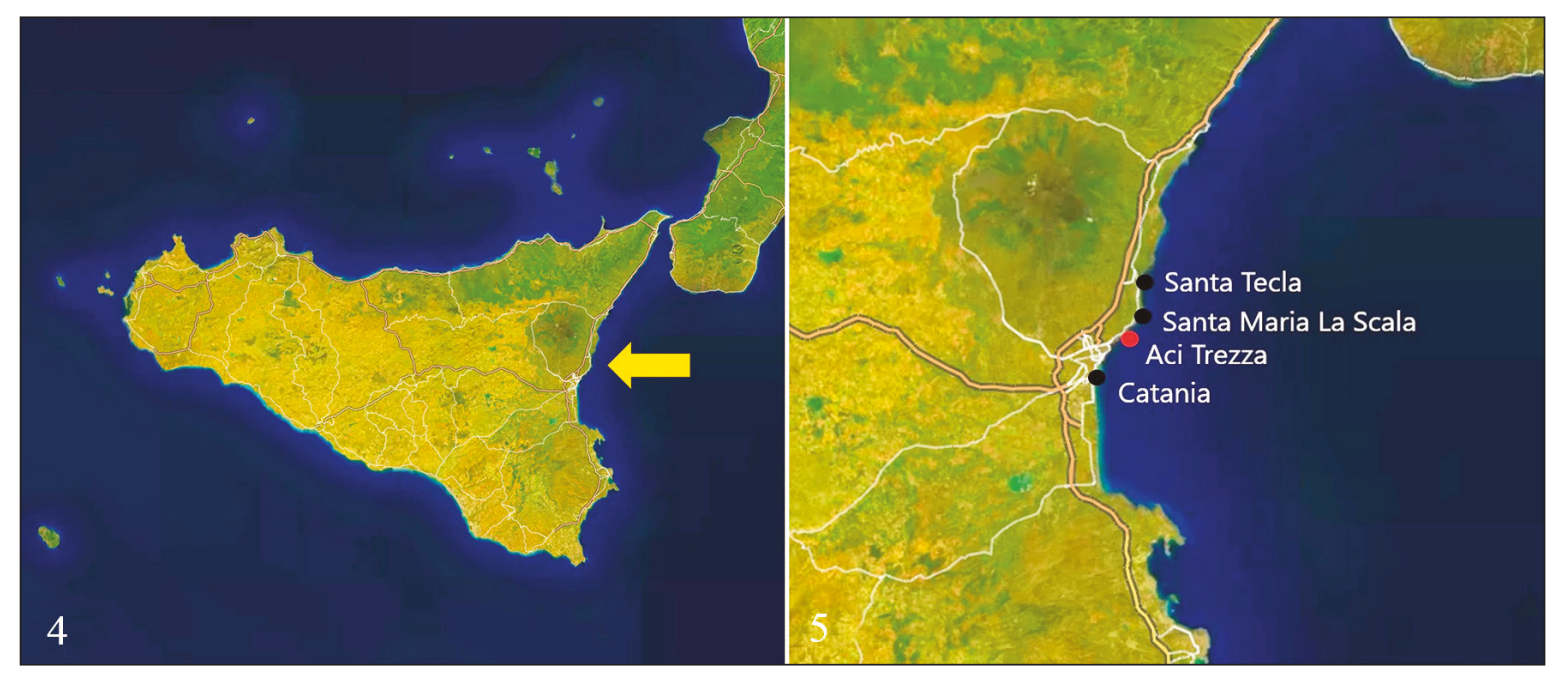

Figures 4, 5. Location of the study area. Fig. 4: The arrow indicates the central-eastern coast of Sicily. Fig. 5: Examined sites (the black dots depict the sites where morning dives were conducted from 2017 to 2020; the red dot shows the site where only sporadic night dives were performed). 


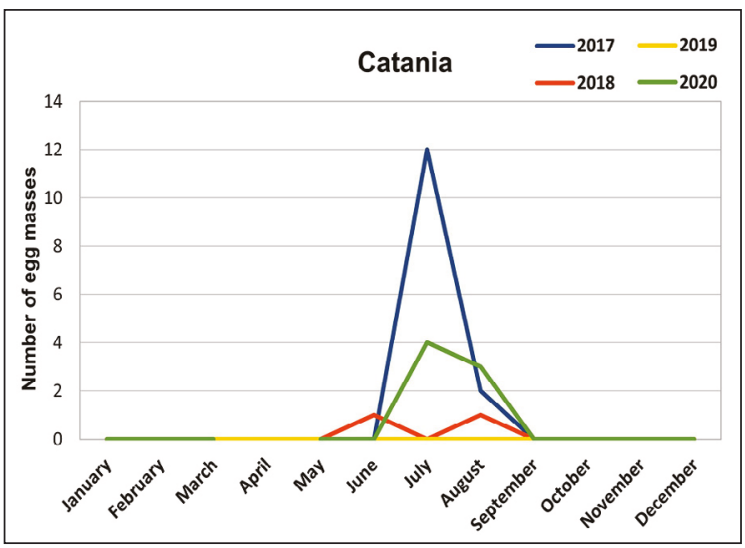

Figure 6. Graphic representation of the total number of egg masses per month found in Catania from 2017 to 2020.

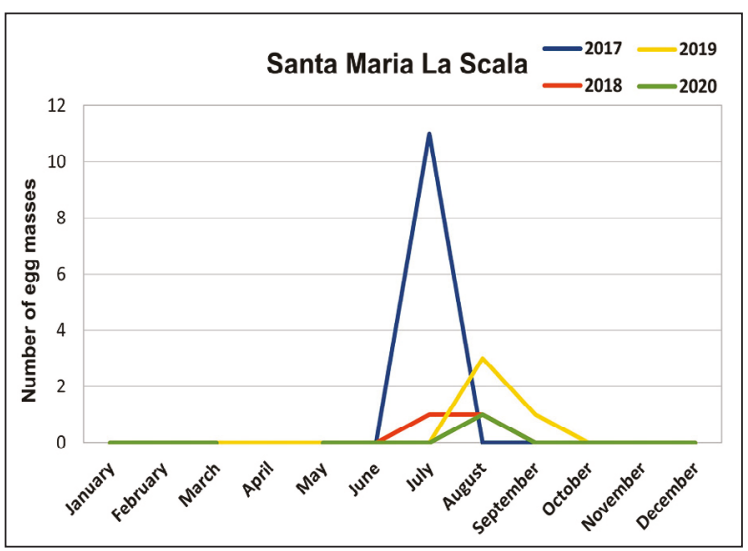

Figure 7. Graphic representation of the total number of egg masses per month found in Santa Maria La Scala from 2017 to 2020 .

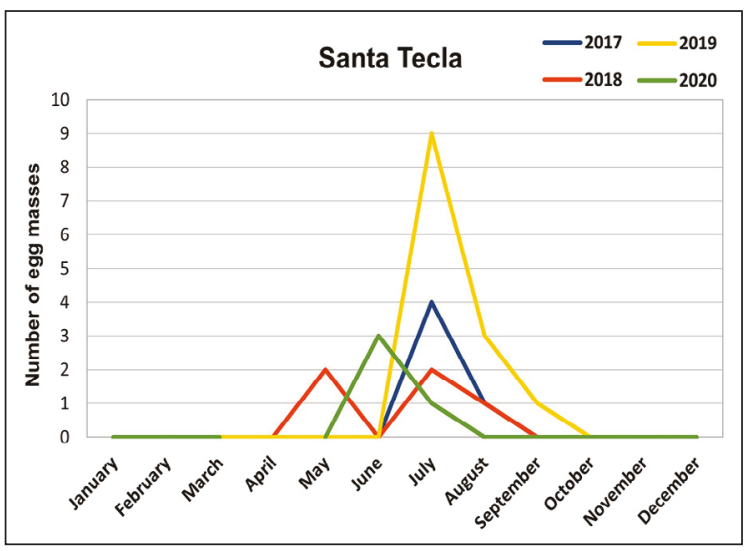

Figure 8. Graphic representation of the total number of egg masses per month found in Santa Tecla from 2017 to 2020.

ducted after 9:00 p.m.) were carried out between 2017 and 2018. During these dives, several P. testudinarius specimens were encountered and photo- graphical and video data were collected and used to obtain information on the behaviour and habits of this species. However, these data were not used for data elaboration.

\section{RESULTS}

\section{Pleurobranchus testudinarius's egg masses}

In the site of Catania (Fig. 6) throughout the period of study (2017-2020) a total of 23 egg masses were observed. In 2017, for this site, the highest number of egg masses (14) were laid. The period of deposition started in July and ended in August. The month in which a higher number of egg masses was found was July, with a total of 12 findings. Instead in August, only two egg masses were found. In 2018 a total of two egg masses, one in June and the other one in August, were documented. In 2019 no egg masses were found. In 2020 a total of seven egg masses (four in July and three in August) were detected. In Catania, $P$. testudinarius's egg masses were documented between 35.4 and $6.5 \mathrm{~m}$ of depth both on photophilous stands in open environments, and on coralligenous bottoms and crevices. In the specific, they were observed on rocky substrates covered by algae of the genera Peyssonnelia Decaisne, Lithophyllum Philippi, Dictyota J. V. Lamouroux, on turf of filamentous red and brown seaweeds and on Palmophyllum crassum (Naccari) Rabenhorst. Moreover, they were seen on substrates characterized by sand mixed with detritus. Catania was the only site, among those of this study, in which a red-violet specimen was found during the day, in August 2017. This specimen was hidden within in a crevice at $5 \mathrm{~m}$ of depth.

In the site of Santa Maria La Scala (Fig. 7), between 2017 and 2020, a total of 18 egg masses were found. In 2017 more egg masses (11) were seen, all in July. In 2018 only two egg masses were observed: one in July and the other in August. In 2019, four egg masses were documented as follows: three in August and one in September. In 2020 only an egg mass was found in August. In Santa Maria La Scala, the egg masses were detected between 36.5 and $5.8 \mathrm{~m}$ of depth, either in photophilous and sciaphilous environments, characterized by the presence of: Peyssonnelia spp., Lithophyllum spp. and on turf of filamentous algae. Moreover, the egg masses were found in ravines with the bryozoan Myriapora trun- 
cata (Pallas, 1766) and sponges, on sand and on bare rock. In this site, throughout the morning dives, no P. testudinarius specimens were found.

In Santa Tecla (Fig. 8), during the period of study, a total of 27 egg masses were documented. In 2017, five egg masses were observed: four in July and one in August. Also in 2018, a total of five egg masses was observed: two in May, two in July and one in August. In 2019 more egg masses (13) were found: nine in July, three in August and one in September. In 2020, overall, four egg masses were detected: three in June and one in July. The egg masses were documented between 45 and $5.6 \mathrm{~m}$ of depth, on sciaphilous rocky bottoms with: the algae Peyssonnelia spp., Lithophyllum spp., P. crassum and the sponge Crambe crambe (Schmidt, 1862). Moreover, the egg masses were found on photophilous bottoms dominated by turf of filamentous algae, bare rock and gravel. Finally, they were observed on sand and detritus. Moreover, in Santa Tecla it was observed that the polychaete Hermodice carunculata (Pallas, 1766) feeds on P. testudinarius's egg masses (Fig. 9).

Also in this site, during the morning dives, no P. testudinarius specimens were seen.

\section{Pleurobranchus testudinarius's specimens}

In the site of Padre Pio, from 2017 to 2018, some sporadic night dives were conducted in August. Through these dives, it was possible to observe several large $P$. testudinarius's specimens in their habitat. In this site, both the chromatic patterns (the orange-yellow and red-violet type) were seen. In an occasion, it was possible to document a specimen during the deposition. This specimen, orange-yellow coloured, presented numerous whitish scars and wounds along a large part of the body (Fig. 10). The great part of the notum that covered the tuberculate gill was missing and, thus, it was possible to easily observe the gill and the egg mass during deposition (Fig. 11). The animal, probably scared by the presence of the authors and scuba lights, retracted the rhinophores. These last presented the apical portions marked by scars (Fig. 12). Another specimen, redviolet coloured, presented part of the distal portion of the left rhinophore that was missing (Fig. 13).

Generally, the encountered specimens did not seem to fear the authors and hardly ever retracted their rhinophores. These last were stretched very
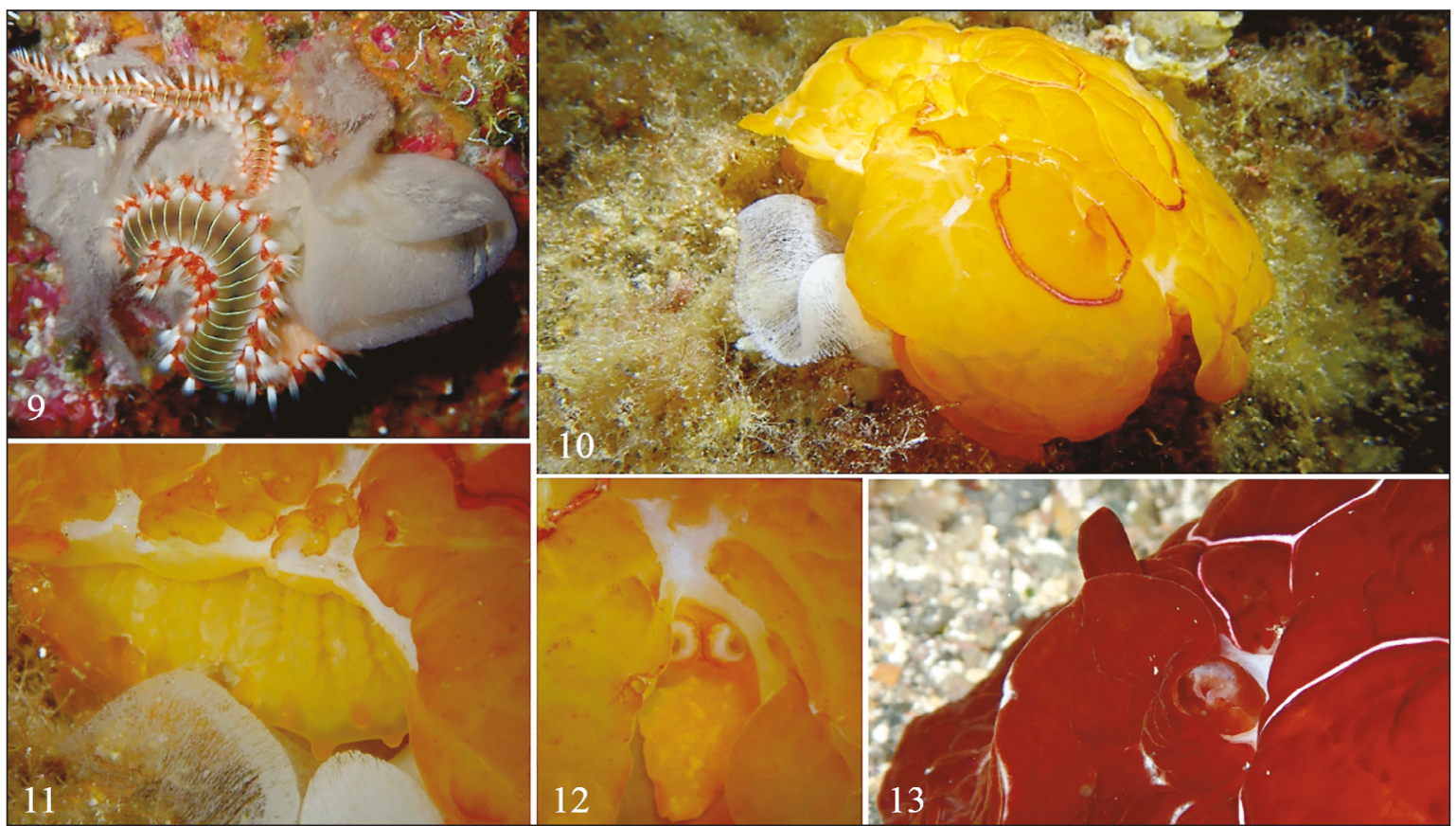

Figures 9-13. Examples of predation on P. testudinarius' $s$ egg masses and scars and injuries on specimens. Fig. 9: two specimens of Hermodice carunculata while feeding on the egg mass of P. testudinarius. Fig. 10: P. testudinarius specimen during deposition, with scars and injuries along the surface of the body. Fig. 11: detail of the missing part of the notum, through which it was possible to see the gill. Fig. 12: detail of the rhinophores and oral veil of the previous specimen. The scars on the rhinophores and on the anterior part of the notum can be noted. Fig. 13: detail of an injury in the left rhinophore of a red-violet specimen (photos by A. Lombardo). 
much and, thanks to rhythmical movements, pumped water in their interior through the apical openings.

\section{DISCUSSION AND CONCLUSIONS}

As already highlighted, P. testudinarius is a species whose biology is not well known. Indeed, the unique information on the lifestyle of this pleurobranch are referred to its nocturnal habit and feed (Ballesteros et al., 2021). First of all, from the data collected through this study, it can be confirmed that $P$. testudinarius is a nocturnal species. In fact, although 311 morning dives were carried out in all months of the years between 2017 and 2020, in the examined areas only a specimen was found in a crevice during the daylight. Instead, in the occasional night dives conducted in August in the site of Padre Pio, several specimens were encountered almost always.

Moreover, it can be noted that along the centraleastern coast of Sicily P. testudinarius lays exclusively during the summer. This strict and precise deposition period together with the large size of this species suggest that $P$. testudinarius is a "strategist"/“K” species (Clark, 1975, Todd, 1981). Consequently, this pleurobranch would belong to the category of "annual" or "biennial" species reported by Todd (1981). The "annual" species have a single generation per year and generally feed on prey with temporary stable cycles. Moreover, these species tend to be of large sizes and particularly conspicuous. Instead, the "biennial" species distinguish from the previous one for the life cycle of almost two years (Todd, 1981). However, there is no certainty in which of these categories $P$. testudinarius is placed. Indeed, it is equally plausible that this species could have an annual or biennial life cycle.

It is noteworthy that this pleurobranch would seem to have natural enemies. Indeed, it was noted that some specimens, encountered in the site of Padre Pio, presented injuries and wounds provoked by a hypothetical predator. Rudman (2002) hypothesised that the scars and the missing parts of the body of $P$. testudinarius could be caused by the fact that, at a certain life stage, this species would not produce or succeed to refill the mantel glands of acid defensive secretions. This would leave the animals without any defences against the attacks of small fishes and crustaceans (Rudman, 2002). It is significant that the most damaged animal, among those encountered during this study, was laying. Therefore, if the hypothesis of Rudmann (2002) would be correct, it is likely that the specimen in deposition was at the end of its cycle.

Beyond the direct attacks, this heterobranch would experience indirect attacks by other animals. In fact, through the morning dives, it was documented that the polychaete $H$. carunculata feeds on the egg masses of $P$. testudinarius. This polychaete, encountered often with high numbers (particularly during summer) in the examined areas, was considered by Righi et al. (2020) as a native invader. This term identifies those species which become invasive in their distribution range (Simberloff, 2011; Carey et al., 2012).

Indeed, $H$. carunculata is a species which is taking over in the infralittoral areas of the Mediterranean, due to the fact that it is a thermophilus species with a generalist nutrition and strong attack and defensive capacities against other animals (Righi et al., 2020). The increase of $1.5^{\circ} \mathrm{C}$ of shallow seawater temperatures in the Mediterranean, observed from 1992 to 2018 (Pastor et al., 2018; Pisano et al., 2020), and the shift of isotherms northwards are enhancing the numerical and geographical explosion of this species (Righi et al., 2020). Consequently, this might represent a threat for several marine heterobranch species, particularly for those that, as P. testudinarius, show annual-biennial life cycles, whose periods of reproduction and deposition are concentrated in a determinate period of the year, when these species canalise all their energies to produce egg masses. Indeed, in the areas of the central-eastern coast of Sicily, the authors observed several times that $\mathrm{H}$. $\mathrm{Ca}$ runculata preyed the egg masses of some marine heterobranch species [e.g., Antiopella cristata (Delle Chiaje, 1841); Cratena peregrina (Gmelin, 1791); Flabellina affinis (Gmelin, 1791) and Platydoris $\operatorname{argo}$ (Linnaeus, 1767)]. Therefore, the predatory activity of $H$. carunculata on P. testudinarius's egg masses could greatly reduce, or even zeroing, the production of new larvae of this species. This could explain the difference in the number of egg masses observed in each site throughout the years of study. For example, the absence of egg masses detected in Catania in 2019 could have been due to a high rate of predation by $H$. carunculata.

In conclusion, through this study, it was indirectly observed that $P$. testudinarius lays exclusively in summer, and that this species might have 
an annual or biennial life cycle. At the same time, comparing the indirect observations (during the day) on a long period and the direct ones (during the night) conducted sporadically, the nocturnal habit of this species can be absolutely confirmed. Moreover, through occasional direct observations, it was seen that this pleurobranch is subjected, probably at the end of its cycle, to attacks of predators. In addition, it was documented that the polychaete $H$. carunculata feeds on the egg masses of $P$. testudinarius and, since this annelid is considered as a native invader, it could represent a threat for the maintenance of $P$. testudinarius populations, as well as other marine annual-biennial heterobranch species, in the waters where it proliferates.

\section{REFERENCES}

Ballesteros M., Madrenas E. \& Pontes M., 2021. "Pleurobranchus testudinarius" in OPK-Opistobranquis. Published: 15/05/2012. Accessed: 16/06/2021. Available at (https://opistobranquis.info/en/dBjSU)

Bandel K., 1976. Egg masses of 27 Caribbean Opisthobranchs from Santa Marta, Columbia. Studies on Neotropical fauna and Environment, 11: 87-118. http://dx.doi.org/10.1080/01650527609360498

Barash A. \& Danin Z., 1971. Opisthobranchia (Mollusca) from the Mediterranean waters of Israel. Israel Journal of Zoology, 20: 151-200.

Carey M.P., Sanderson B. L., Barnas K.A. \& Olden J.D., 2012. Native invaders-challenges for science, management, policy. And society. Frontiers in Ecology and the Environment, 10: 373-381. https://doi.org/10.1890/110060

Cattaneo-Vietti R., 1986. On Pleurobranchomorpha from Italian Seas (Mollusca: Opisthobranchia). The Veliger, 28: 302-309.

Cervera J. L., Calado G., Gavaia C., Malaquias M. A. E., Castaño J. T., Ballesteros M., Megina Martínez C. \& García-Gómez J. C., 2004. An annotated and updated checklist of the opisthobranchs (Mollusca: Gastropoda) from Spain and Portugal (including islands and archipelagos). Boletín del Instituto Español de Oceanografía, 20: 5-115.

Clark K.B., 1975. Nudibranch life cycles in the Northwest Atlantic and their relationship to the ecology of fouling communities. Helgo Einderwiss Meeresunters, 27: 28-69. https://doi.org/10.1007/BF01611686

Ergüden D., Ayas D., Alagöz Ergüden S. \& Uygur N., 2019. Occurence of Pleurobranchus testudinarius Cantraine, 1835 in Iskenderun Bay, Turkey (Southern Mediterranean). Biharean Biologist, 14: 49-51.
Gökoğlu M., Teker S. \& Gökoğlu K., 2018. Rarely seen turtle snail (Pleurobranchus testudinarius Cantraine, $1835)$ on the shores of Phaselis ancient city in the Mediterranean. Phaselis, 4: 177-180.

http://dx.doi.org/10.18367/Pha.18011

Horst D., 2008. (Jul 14) Re: Pleurobranchus from the French Mediterranean. [Message in] Sea Slug Forum. Australian Museum, Sydney. Available from http://www.seaslugforum.net/find/21698

Lombardo A. \& Marletta G., 2020. The biodiversity of the marine Heterobranchia fauna along the centraleastern coast of Sicily, Ionian Sea. Biodiversity Journal, 11: 861-870.

https://doi.org/10.31396/Biodiv.Jour.2020.11.4.861. 870

Marcus Ev., 1970. Opisthobranchs from Northern Brazil. Bulletin of Marine Science, 20: 922-951.

Martynov A.V. \& Schrödl M., 2009. The new Arctic sidegilled sea slug genus Boreoberthella (Gastropoda, Opisthobranchia): Pleurobranchoidean systematics and evolution revisited. Polar Biology, 32: 53-70. https://doi.org/10.1007/s00300-008-0503-3

Mpardanis M., 2007. (Nov 13) Pleurobranchus from Cyclades, Aegean Sea. [Message in] Sea Slug Forum. Australian Museum, Sydney. Available from http://www.seaslugforum.net/find/21071

Pastor F., Valiente J.A. \& Palau J.L., 2018. Sea surface temperature in the Mediterranean: Trends and spatial patterns (1982-2016). In: Vilibić I., Horvath K. \& Palau J.L. 2018. Meteorology and Climatology of the Mediterranean and Black Seas. Springer., Berlin/Heidelberg, Germany, pp. 297-309.

Pisano A., Marullo S., Artale V., Falcini F., Yang C., Leonelli F. E., Santoleri R. \& Nardelli B.B., 2020. New Evidence of Mediterranean Climate Change and Variability from Sea Surface Temperature Observations. Remote Sensing, 12: 132. https://doi.org/10.3390/rs12010132

Poursanidis D., 2007. (Sep 18) Pleurobranchus testudinarius from the Aegean Sea. [Message in] Sea Slug Forum. Australian Museum, Sydney. Available from http://www.seaslugforum.net/find/20746

Poursanidis D., Koutsoubas D., Issaris J., Gerovasileiou V. \& Zenetos A. 2009. New recors on the opisthobranch fauna of the Greek seas. Marine Biodiversity Records 2: e74. https://doi.org/10.1017/S1755267209000475

Pruvot-Fol A., 1954. Fauna de France. Mollusques opisthobranches. Lechevalier, Paris, 461 pp.

Righi S., Prevedelli D. \& Simonini R., 2020. Ecology, distribution and expansion of a Mediterranean native invader, the fireworm Hermodice carunculata (Annelida). Mediterranean Marine Science, 21: 558-574. https://doi.org/10.12681/mms.23117

Ros J. \& Gili J.M., 1984. Opisthobranches des grottes sous-marines de l'Ile de Majorca (Baleares). C. I. E. 
S. M., XXIX ${ }^{\mathrm{e}}$ Congrès-Assemblée plénière, Lucerne, 11-19 Octobre 1984. Session commune BenthosPénétration de l'Homme sous la mer: Le peuplement des grottes: $1-4$.

Rudman W.B., 2002. (Jun 15). Comment on Re: Pleurobranchus from Turkey by Jim Anderson. [Message in] Sea Slug Forum. Australian Museum, Sydney. http://www.seaslugforum.net/find/7257

Simberloff D., 2011. Native invaders. In: Simberloff D. \& Rejmánek M. 2011. Encyclopedia of biological invasions. University of California Press., Berkeley and Los Angeles, CA. 472-475.

Todd C.D., 1981. The ecology of nudibranch molluscs. Oceanography and Marine Biology, An Annual Review, 19: 141-234
Trainito E. \& Doneddu M., 2014. Nudibranchi del Mediterraneo. Il Castello, Cornaredo, 192 pp.

Vayssière A., 1898. Monographie de la famille des Pleurobranchidés. Annales des Sciences Naturelles, 8: 209-402.

Wirtz P. \& Martins H.R., 1993. Notes on some rare and little known marine invertebrates from the Azores, with a discussion of the zoogeography of the region. Arquipélago. Life and Marine Sciences, 11 A: 5563.

Yokes B., 2002. (Jun 14) Pleurobranchus testudinarius from Turkey. [Message in] Sea Slug Forum. Australian Museum, Sydney. Available from http://www.seaslugforum.net/find/7200 